\title{
Physicochemical Characteristics and Microbial Contamination of Raw Milk and Artisanal Milk Curd (Nonnon koumou) in Daloa, Côte D'ivoire
}

\author{
Assohoun-Djeni Nanouman Marina Christelle ${ }^{1,2,3, *}$, Kouassi Kouassi Clément ${ }^{1,2}$, Kouassi \\ Kra Athanase ${ }^{1,2}$, Yao Kouassi Cédric ${ }^{2}$, Djeni N'dédé Théodore ${ }^{3}$ and Konate Ibrahim ${ }^{1,2}$ \\ ${ }^{1}$ University Jean Lorougnon Guédé, Unit training and Agroforestry Research, Teaching Unit \\ Biochemistry, Microbiology BP150 Daloa, Côte d'Ivoire \\ ${ }^{2}$ University Jean Lorougnon Guédé, Unit training and Agroforestry Research, Laboratory of \\ Microbiology, Bio-industry and Biotechnologie BP150 Daloa, Côte d'Tvoire \\ ${ }^{3}$ University Nangui Abrogoua, Department of Food Science and Technology, Laboratory of \\ Biotechnology and Food Microbiology, 02 BP 801 Abidjan 02 Côte d'Ivoire \\ *Corresponding author
}

\section{A B S T R A C T}

Cow's milk is sought for its high concentration of animal protein and nutrients. Unfortunately, the conditions of milking, transport, packaging and marketing of milk in Daloa (Côte d'Ivoire) jeopardize its microbiological quality. Our study aimed to study the physicochemical and

\section{Ke y w o r d s}

Milk, nonnonkoumou, fermentation, lactic acid bacteria, contamination

\section{Article Info}

Accepted:

20 February 2020

Available Online:

10 March 2020 microbiological characteristics of raw milk (collected from pastures and sellers) and artisanal curd (nonnonkoumou). A total of 33 samples underwent physicochemical analysis. This analysis consisted of determination of $\mathrm{pH}$, titratable acidity, and density. Microbiological analysis consisted of enumeration of lactic acid bacteria, yeasts and molds, Aerobic mesophiles, total and thermotolerant coliforms, and Salmonella research. A survey was also conducted to determine the knowledge, mode and frequency of milk consumption. This survey has shown that milk is known and consumed by many Ivorians and some nationals of neighboring countries of any age and any social level. The physicochemical analyzes revealed a low $\mathrm{pH}$ (between $3.7 \pm 0.007$ and $3.9 \pm 0.02$ ) in the nonnonkoumou compared to that of the milk (between $5.9 \pm 0.02$ and $6.7 \pm 0.007$ ). Titratable acidity ranged from $1.4 \pm 0.007$ to $1.34 \pm 0.007$ in nonnonkoumou and from $0.36 \pm 0.01$ to $0.08 \pm 0.007$ in milk. Densities of milk and nonnonkoumou ranged from $0.841 \pm 0.007$ to $1.072 \pm 0.02$. Microbiological analyzes of milk samples taken from pastures showed similar loads (between $4.81 \pm$ 0.4 and $6.88 \pm 0.73 \log \mathrm{CFU} / \mathrm{ml}$ ) in fermentative germs and contaminants. In addition, the milk collected from the sellers was free of yeasts and molds and the total and thermotolerant coliforms were not detected in the nonnonkoumou samples analyzed. Salmonella (pathogenic flora) was detected in some milk samples analyzed thus demonstrating that this milk is of poor microbiological quality. Its consumption can lead to a food poisoning.

\section{Introduction}

Milk and dairy products contain many nutrients, such as protein, vitamins, calcium, phosphorus, magnesium, zinc, etc., which are necessary for healthful living of humans of all age groups and both sex (Das et al., 2015). As a concentrated source of macro- and micronutrients, milk and dairy products can play a particularly important role in human nutrition in developing countries, where the diets of poor people such as those in Côte d'Ivoire frequently lack diversity and consumption of animal source foods may be 
limited (Muehlhoff, 2013). In Côte d'Ivoire, domestic production of artisanal milk is low and covers only $17 \%$ of overall milk consumption (Mirah-Dpp, 2012). To improve milk production, the country has set up, through development projects such as the Laitier Sud Project, small dairy farms mainly in peri-urban areas. To this end, small dairy farms are created in the peripheral areas of Abidjan town and other major cities (Daloa, Korogho.) of Côte d'Ivoire by officials or Ivorian or foreign businessmen who entrusted the management to the fulani from Mali, Burkina Faso or Guinea.

Thus, the largest quantity of milk produced is sold directly to consumers by breeders and small traders in informal, uncontrolled markets. (Youan-Bi, 2008).

The raw milk rapid degradation under the effect of the relatively high ambient temperatures characterizing tropical countries has forced actors in the "milk" sector to develop conservation or processing techniques adapted to the socio-economic and environmental context (Kèkè et al., 2009).

In Côte d'Ivoire, for example, cow's milk is transformed, apart from direct domestic consumption, into nonnonkoumou, a spontaneous fermented curd. The present fermentation of the artisanal milk is a spontaneous fermentation initiated by natural microorganisms that are found on raw materials, on the processing utensils/equipments, on the hands of producers and from the local atmosphere as natural starters (Jespersen et al., 1994).

Despite its importance in the diet of large groups of people, the lack of control of fermentation process unavoidably results in significant variation in the quality and microbiological safety of this food (VieiraDalode et al., 2008). Milk and nonnonkoumou are subject to microbial contaminations and also to losses of their nutritional and market quality, due to limitations of traditional methods of production and conservation of these products.

Also, the unhygienic conditions of milking, transport, packaging and marketing of these perishable foodstuffs limit the provision to consumers of irreproachable quality products. So milk and dairy products can harbor a variety of organisms, including many zoonotic bacteria such as Brucella abortus, Brucella. melitensis, Campylobacter jejuni, Escherchia coli, Listeria monocytogens, Mycobacterium bovis, Mycobacterium tuberculosis, Salmonella, Staphylococcus aureus, and Yersinia enterocolitica, which can cause serious diseases, especially in children, pregnant women, elderly, and compromised individuals ( $\mathrm{Pal}, 2007$; FAO, 2013).

Furthermore diarrheal diseases, which include cholera and typhus as well as gastroenteritis, cause about 6 percent of all deaths throughout the world (Olshansky et al., 1997). To ensure a better microbiological quality of the raw cow's milk consumed by the Ivorian population, control of the process from the extraction of artisanal milk from pasture to commercialization would therefore be necessary. However, to our knowledge, no or few studies has been done on raw cow's milk extracted from pastures, as well as that of the sellers of Daloa town in Côte d'Ivoire.

The objective of this work was to study the physicochemical and microbiological characteristics of artisanal milk taken from pastures and from milk resellers and artisanal milk curd (nonnonkoumou) in Daloa. It will also be necessary to know the level of consumption of artisanal milk through a survey. 


\section{Materials and Methods}

\section{Survey of the consumption of artisanal milk}

A preliminary survey allowed to identify pastures in Daloa town and to design a questionnaire of inquiry-consumption dedicated to milk consumers. The surveyed population consists of passers-by met on the main streets and side streets of five districts of Daloa town and volunteering to answer the questionnaire. In total, one hundred and fifty people were interviewed, with an average of about 30 people per ward. The survey consisted of a direct interview with the volunteers. This interview focused on the socio-demographic profile (age, study level...) of the consumer, his knowledge of milk, his mode and frequency of milk consumption and the appearance of possible symptoms of food poisoning (vomiting, diarrhea ...) related to the consumption of this food.

\section{Sampling}

Artisanal milk taken from four shepherds in pastures and from four (4) milk resellers and three (3) nonnonkoumou sellers were concerned by the sampling realized in Daloa town, Côte d'Ivoire. Three (03) samples of each product were collected by pasture and by seller. A total of thirty three (33) samples including twenty four for milk and nine for nonnonkoumou were collected in sterile containers and transported immediately in an icebox directly to the laboratory for analyses.

\section{Physico-chemical analysis}

The physico-chemical analysis was realized according to standard methods. $\mathrm{pH}$ values of the samples were measured by directly immersing the electrode of an electronic $\mathrm{pH}$ meter (Microprocessor $\mathrm{pH}$ meter, $\mathrm{pH} 211$, HANNA Instruments) in $20 \mathrm{ml}$ of milk. Total titratable acidity (TA) was measured by titrating $10 \mathrm{~mL}$ of milk against $0,1 \mathrm{~N}$ sodium hydroxide $(\mathrm{NaOH})$ solution using phenolphthalein as indicator (Kimaryo et al., 2000). To deduce the fraudulent practices of the sellers by adding external elements, the density of the milk samples of each seller was determined according to the formula using by Pointurier, 2003.

\section{Enumeration of microorganisms}

Preparation of stock solutions, inoculation of agar plates, and cultivation and quantification of microorganisms were carried out according to Coulin et al., 2006. For all determinations, $10 \mathrm{ml}$ of the sample were homogenized in a stomacher with $90 \mathrm{ml}$ of sterile diluent containing $0.85 \% \mathrm{NaCl}$ and $0.1 \%$ peptone (Difco, Becton Dickinson, Sparks, MD, USA). Tenfold serial dilutions of stomacher fluid, ranging from $10^{1}$ to $10^{7}$, were prepared and spread-plated for the determination of microbial counts. So, enumeration of coliforms was carried out using VRBL (Violet crystal and neutral Red Bile Lactose) plates containing agar (VRBL agar, Oxoid Ltd., Basingstore, UK), incubated for $24 \mathrm{~h}$ at $30{ }^{\circ} \mathrm{C}$ for total coliforms and $44{ }^{\circ} \mathrm{C}$ for fecal coliforms. Yeasts and molds were enumerated on Sabouraud chloramphenicol agar (Fluka, Biochemica 89579, Sigma-Aldrich Chimie $\mathrm{GmbH}$, India) incubated at $30{ }^{\circ} \mathrm{C}$ for 4 days. Aerobic mesophiles were enumerated on Plate Count Agar (PCA Oxoid.) and incubated at $30^{\circ} \mathrm{C}$ for 2 days. Enumeration of LAB was carried out using Man, Rogosa and Sharpe (MRS) agar (Merck, Darmstadt, Germany), which were incubated under anaerobic conditions (Anaerocult A, Merck) at $37^{\circ} \mathrm{C}$ for $72 \mathrm{~h}$. Highlighting Salmonella $s p$ is done in three stages (Pre-enrichment, enrichment and isolation) according to the reference standard NF/ISO 6579:2002 Amd 1: 2007. Preenrichment is performed in media Buffered Peptone Water (BPW) by incubating the stock solution at $37^{\circ} \mathrm{C}$ for $24 \mathrm{~h}$. The enrichment consisted of taking $0.1 \mathrm{~mL}$ of the stock 
solution (pre-enriched) and transferred to a tube containing $10 \mathrm{~mL}$ of Vassiliadis Rappaport broth previously prepared and sterilized. After homogenization, the tube is incubated at $42^{\circ} \mathrm{C}$ for $24 \mathrm{~h}$. Finally the isolation was carried out from the enrichment medium incubated on a solid selective medium: Hecktoen agar. A drop is taken using a Pasteur pipette and then seeded by streaks on the surface of the Hecktoen agar. The dish is incubated at $37^{\circ} \mathrm{C}$ for $24 \mathrm{~h}$, and sometimes even for $48 \mathrm{~h}$, in the absence of characteristic colonies after the first incubation. On Hecktoen agar, the typical Salmonella colonies observed are green or blue with a black center.

\section{Statistical analysis}

All trials were repeated four times. The different sample treatments were compared by performing one-way analysis of variance on the replicates at a $95 \%$ level of significance using the Statistica (99th Ed, Alabama, USA) statistical program. Unless otherwise stated, significant results refer to $\mathrm{P}<0.05$. This software was also used to calculate mean values and standard deviations of the trials.

\section{Results and Discussion}

\section{Milk consumption}

Of all the individuals interviewed during milk consumption survey in Daloa City, 53.33\% were female and $44.66 \%$ were male. The age of these individuals ranged between 14 and 50 years or more with individuals majority $(38.67 \%)$ in between the $25-50$ age group. Among these individuals, $30 \%$ have no schooling level, $14 \%$ the primary level, the majority $(37.33 \%)$ the upper level and the rest (18.67\%) the secondary level. Most of them are pupils $(16.67 \%)$, students $(31.33 \%)$, civil servants (10.67\%) and craftsmen (18.67). But, $9.33 \%$ of them do not exercise or more professional activity. These individuals were mostly single $(57.33 \%)$ and most of them were Ivorian $(84.67 \%)$. These individuals were mostly single $(57.33 \%)$ and most of them were Ivorian $(84.67 \%)$ (Table I).

The milk consumption survey has shown that milk is very well known and widely consumed. Indeed, $100 \%$ of the people interviewed knew this food well and consumed it all (100\%) regularly and generally at breakfast time (45.33\% of the individuals). The majority (61.33\%) consumed it at least once a week, but others did it twice (14\%) or even more $(24.67 \%$ ) a week. The budget for the consumption of milk could rise in some cases to more than 500 FCFA (for $15.33 \%$ of individuals) per day, but the majority (49.33\%) spent between 100 and 200 FCFA per day to consume milk. Preference was given to boiled milk (40.67\%), followed by fermented milk or nonnonkoumou $(32 \%)$ and finally raw milk (27.33) (Table II).

According to the survey results, milk consumption was associated with disorders. Indeed, $46 \%$ of those questioned said they had had the ailments after drinking milk, compared with $54 \%$ of those who answered the opposite. The symptoms associated with these ailments were mainly diarrhea $(89.85 \%)$ and gastroenteritis $(10.15 \%)$. Thus most of the discomfort lasted on average 1 day $(60.87 \%)$. However some lasted 2 days $(30.43 \%)$ or more $(8.70 \%)$. In addition, only $2.89 \%$ of the ailments mentioned required hospitalization compared to $97.10 \%$ (Table III).

\section{Change in pH, total titratable and density}

The $\mathrm{pH}$ of the milk samples taken from the pastures and from the sellers is relatively high compared to the $\mathrm{pH}$ of nonnonkoumou samples. Thus, the lowest $\mathrm{pH}$ is that of the 
milk taken from pasture $3(5.9 \pm 0.02)$ while the $\mathrm{pH}$ of the milk taken from resellers 3 and 4 is highest with a value equal to $6.7 \pm 0.007$. These $\mathrm{pH}$ values are negatively correlated with the titratable acidity rate which varies from $0.36 \pm 0.01$ to $0.08 \pm 0.02$. On the other hand, nonnonkoumou samples have lower $\mathrm{pH}$ values ranging from $3.7 \pm 0.001$ to $3.9 \pm 0.02$.

The titratable acidity level of nonnonkoumou 2 and 3 is $1.4 \pm 0.007$ and that of nonnonkoumou 1 is $3.9 \pm 0.02$. The density of the milk collected in the pasture 4 and at the reseller 4 is equal to $1.029 \pm 0.01$. Also, the density of milk taken from the other 3 pastures and the other 3 resellers is between $1.04 \pm 0.01$ and $1.071 \pm 0.01$. The nonnonkoumou samples density varies from 0.832 to 0.860 (Table IV).

\section{Enumeration of the different bacterial groups}

Enumeration of microorganisms in this study showed that LAB and yeasts and molds had similar growth in the milk samples taken from pastures and their counts in this milk were not significantly different $(\mathrm{P}<0.05)$ (Fig. 1). Indeed, the load of lactic acid bacteria $(8.33 \pm$ $0.5 \log \mathrm{CFU} / \mathrm{ml}$ ) is higher in the pasture milk 2 while that of yeasts and mold $(6.88 \pm 0.73$ $\log \mathrm{CFU} / \mathrm{ml}$ ) is higher in the pasture milk 1 . The lowest loads of $6.23 \pm 0.45 \log \mathrm{CFU} / \mathrm{ml}$ for lactic acid bacteria and $5.10 \pm 0.15 \mathrm{log}$ $\mathrm{CFU} / \mathrm{ml}$ for yeasts and molds are observed respectively in pasture milk 1 and 4 (Fig. 1).

The higher count of LAB was $5.94 \pm 0.27 \mathrm{log}$ CFU / $\mathrm{ml}$ in the reseller milk 2. The milk collected from reseller 3 contains less LAB with a load of $5.66 \pm 0.45 \log \mathrm{CFU} / \mathrm{ml}$. In addition, the milk collected from the resellers was free of yeasts and molds (Fig. 2).

The yeast and mold loads in nonnonkoumou 1,2 and 3 are substantially identical (from $5.94 \pm 0.26 \log \mathrm{CFU} / \mathrm{ml}$ to $6.12 \pm 0.44 \mathrm{log}$
CFU / ml) while the load in LAB are higher (5.52 $\pm 0.53 \log \mathrm{CFU} / \mathrm{ml})$ in nonnonkoumou 1 and lower $(3.28 \pm 0.46 \log \mathrm{CFU} / \mathrm{ml})$ in nonnonkoumou 3 (Fig. 3 ).

The pasture milk 4 contains the highest loads of aerobic mesophiles $(6.53 \pm 0.4 \log \mathrm{CFU} /$ $\mathrm{ml})$, total coliforms $(5.73 \pm 0.42 \log \mathrm{CFU} /$ $\mathrm{ml})$ and fecal coliforms $(5.11 \pm 0.38 \log \mathrm{CFU}$ / $\mathrm{ml}$ ). On the other hand, the pasture milk 3 contains the lowest number of contaminating germs with loads of $4.98 \pm 0.18 \log \mathrm{CFU} / \mathrm{ml}$ for aerobic mesophiles, $4.89 \pm 0.35 \log \mathrm{CFU} /$ $\mathrm{ml}$ for total coliforms and $4.81 \pm 0.4 \log \mathrm{CFU}$ / $\mathrm{ml}$ for fecal coliforms (Fig. 4).

The aerobic mesophiles load is higher $(6.36 \pm$ $0.3 \log \mathrm{CFU} / \mathrm{ml}$ ) in the reseller milk 4 and lower $(5.52 \pm 0.41 \log \mathrm{CFU} / \mathrm{ml})$ in reseller milk 1 . The number of total coliforms $(5.74 \pm$ $0.13 \log \mathrm{CFU} / \mathrm{ml}$ ) and thermotolerant coliforms $(5.37 \pm 0.28 \log \mathrm{CFU} / \mathrm{ml})$ was higher in reseller milk 2. Minimum loads are $5.06 \pm 0.3 \log \mathrm{CFU} / \mathrm{ml}$ for total coliforms and $4.98 \pm 0.33 \log \mathrm{CFU} / \mathrm{ml}$ for thermotolerant coliforms respectively in reseller milk 1 and reseller milk 4 (Fig. 5).

The Figure 6 shows the count of contaminating germs in nonnonkoumou samples. Indeed, the aerobic mesophiles loads in nonnonkoumou samples 1, 2 and 3 are substantially identical with values ranging from $6.68 \pm 0.27 \log \mathrm{CFU} / \mathrm{ml}$ to $6.86 \pm 0.17$ $\log \mathrm{CFU} / \mathrm{ml}$. Moreover it is important to note that no coliforms (both total and thermotolerant) was detected in nonnonkoumou samples analyzed. Salmonella identification in milk and nonnonkoumou samples is presented in Table V. Thus, this table shows the presence of salmonella in the pastures milk 1 and 3 and in the reseller milk 1. Moreover it is important to note that no salmonella was detected in nonnonkoumou samples and in the other milk samples analyzed. 
Table.1 Sociodemographic profile of individuals interviewed during the milk consumption survey conducted in the districts of Daloa city

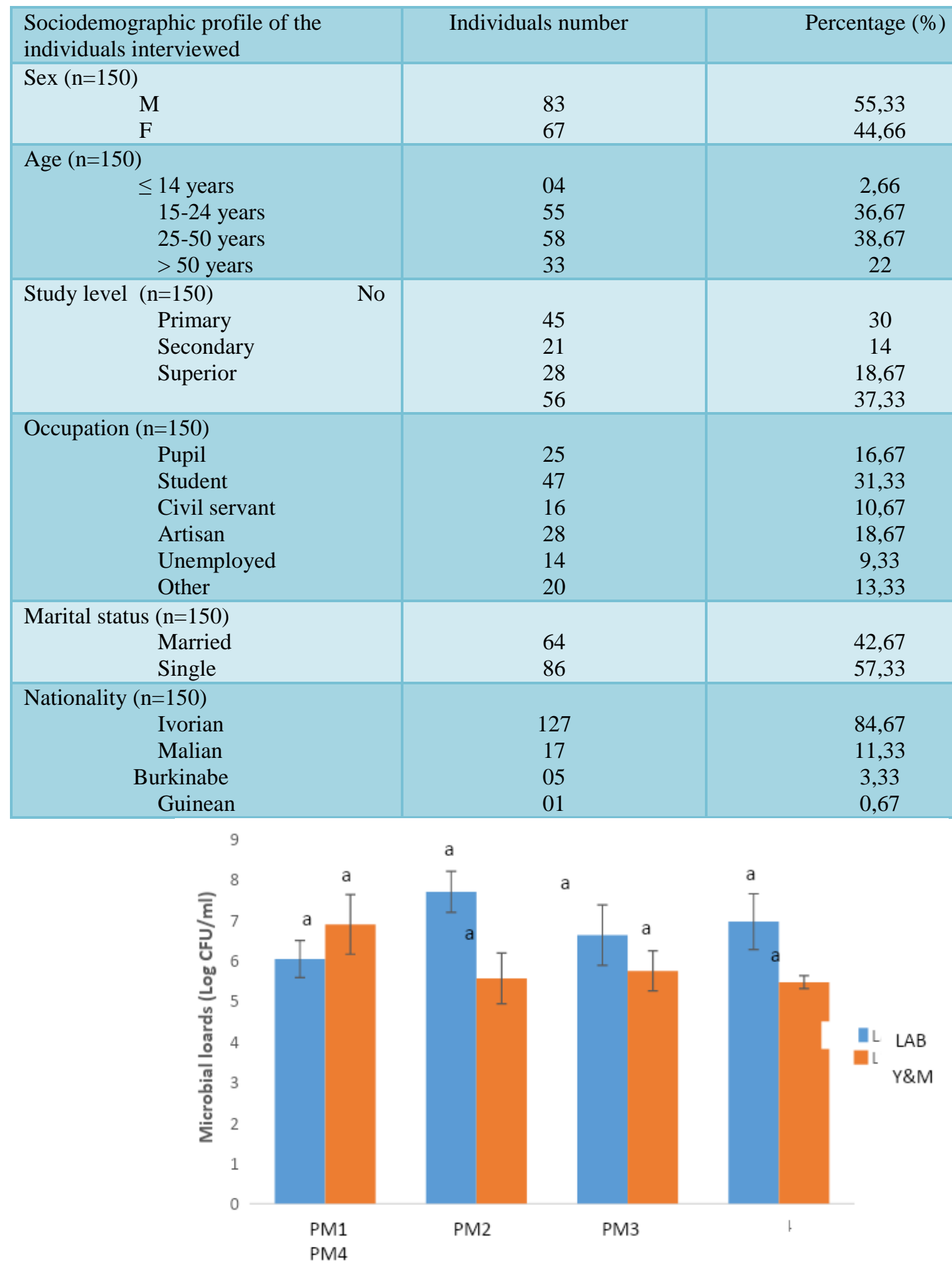

Fig. 1. Lactic acid bacteria and yeasts and molds (fermenting microorganisms) populations in milk samples taken from pastures. Values at each time point are the means of our replicates \pm SD (error bars). LAB: Lactic acid bacteria, Y\&M: Yeast and molds. PM1, PM2, PM3, PM4: Pasture milk 1, 2, 3 and 4. For the same type of germ, histograms bearing the same alphabetical letter are not statistically different $(\mathrm{P}>0.05)$ (Tukey, HSD). 
Table.2 Some aspects of milk consumption by the individuals interviewed during the consumption survey conducted in the districts of Daloa city.

\begin{tabular}{|c|c|c|}
\hline Raw milk Consumption aspects & Individuals number & Percentage $(\%)$ \\
\hline $\begin{array}{c}\text { Milk Knowledge }(\mathrm{n}=150) \\
\text { Yes } \\
\text { No }\end{array}$ & $\begin{array}{c}150 \\
00\end{array}$ & $\begin{array}{c}100 \\
0\end{array}$ \\
\hline $\begin{array}{ll}\text { Milk consumption }(\mathrm{n}=150) & \text { Yes } \\
\text { No } & \end{array}$ & $\begin{array}{c}150 \\
00\end{array}$ & $\begin{array}{c}100 \\
0\end{array}$ \\
\hline $\begin{array}{l}\text { Day moments }(\mathrm{n}=150) \\
\text { Breakfast } \\
\text { Lunch } \\
\text { Dinner } \\
\text { Other }\end{array}$ & $\begin{array}{l}68 \\
21 \\
37 \\
24\end{array}$ & $\begin{array}{c}45,33 \\
14 \\
24,67 \\
16\end{array}$ \\
\hline $\begin{array}{l}\text { Times number a day }(\mathrm{n}=150) \\
\text { One time } \\
\text { Two times } \\
\text { Thrice } \\
\text { Other }\end{array}$ & $\begin{array}{l}92 \\
21 \\
00 \\
37\end{array}$ & $\begin{array}{c}61,33 \\
14 \\
00 \\
24,67\end{array}$ \\
\hline $\begin{array}{l}\text { The amount spent on buying milk by day }(\mathrm{n}=150) \\
\qquad \begin{array}{l}100-200 \mathrm{~F} \\
200-500 \mathrm{~F} \\
500 \mathrm{~F}+\end{array}\end{array}$ & $\begin{array}{l}74 \\
53 \\
23\end{array}$ & $\begin{array}{l}49,33 \\
35,33 \\
15,33\end{array}$ \\
\hline $\begin{array}{l}\text { Types of milk consumed }(\mathrm{n}=150) \\
\qquad \begin{array}{l}\text { Raw } \\
\text { boiled } \\
\text { fermented }\end{array}\end{array}$ & $\begin{array}{l}41 \\
61 \\
48\end{array}$ & $\begin{array}{c}27,33 \\
40,67 \\
32\end{array}$ \\
\hline
\end{tabular}

7

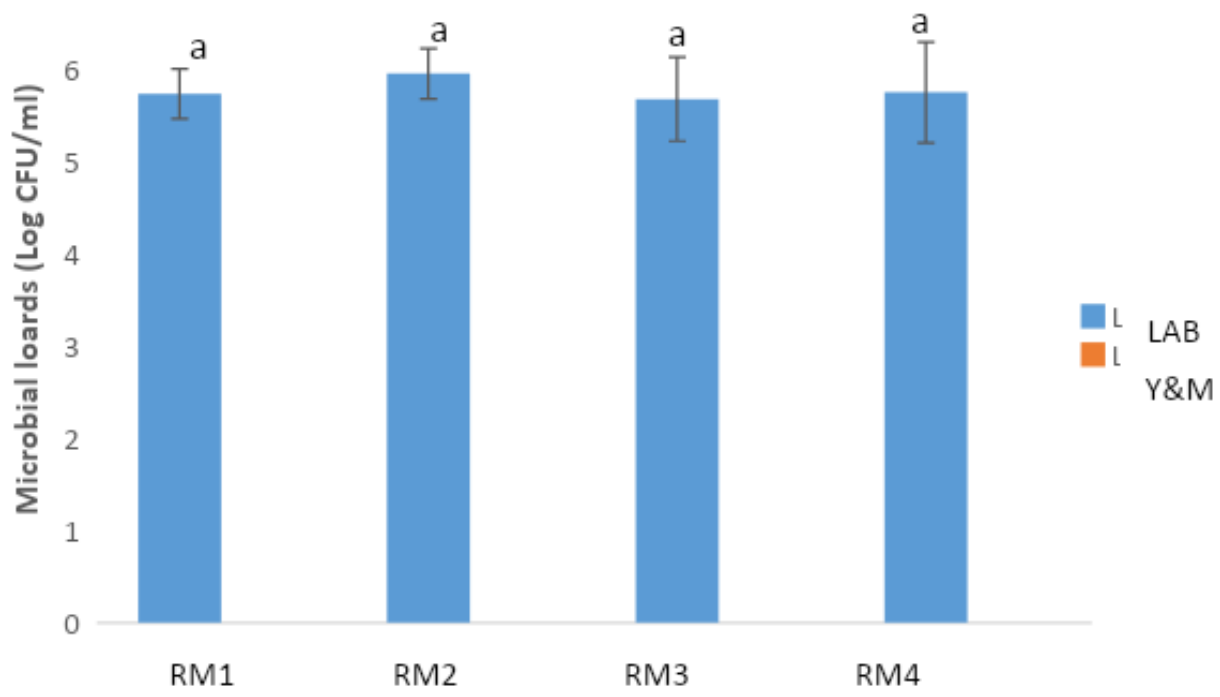

Fig. 2. Lactic acid bacteria and yeasts and molds (fermenting microorganisms) populations in milk samples taken from resellers. Values at each time point are the means of our replicates \pm SD (error bars). LAB: Lactic acid bacteria, Y\&M: Yeast and molds. RM1, RM2, RM3, RM4: Resellers milk 1, 2, 3 and 4. For the same type of germ, histograms bearing the same alphabetical letter are not statistically different $(\mathrm{P}>0.05)$ (Tukey, HSD). 
Table.3 Consequences possibly linked to milk consumption by the individuals interviewed in the districts of Daloa city.

\begin{tabular}{|c|c|c|}
\hline Consequences linked to milk consumption & $\begin{array}{c}\text { Individuals } \\
\text { number }\end{array}$ & Percentage $(\%)$ \\
\hline $\begin{array}{l}\text { Ailments after milk consumption }(\mathrm{n}=150) \\
\text { Yes } \\
\text { No }\end{array}$ & $\begin{array}{l}69 \\
81\end{array}$ & $\begin{array}{l}46 \\
54\end{array}$ \\
\hline $\begin{array}{l}\text { Symptoms of ailments }(\mathrm{n}=69) \\
\text { Fever } \\
\text { Vomiting } \\
\text { Diarrhea } \\
\text { Boating } \\
\text { Gastroenteritis }\end{array}$ & $\begin{array}{c}00 \\
00 \\
62 \\
00 \\
7\end{array}$ & $\begin{array}{c}00 \\
00 \\
89,85 \\
00 \\
10,15\end{array}$ \\
\hline $\begin{array}{l}\text { Duration of ailments }(\mathrm{n}=69) \\
\qquad \begin{array}{l}1 \text { days } \\
2 \text { days } \\
3 \text { days } \\
\text { other }\end{array}\end{array}$ & $\begin{array}{l}42 \\
21 \\
00 \\
06\end{array}$ & $\begin{array}{c}60,87 \\
30,43 \\
00 \\
08,70\end{array}$ \\
\hline $\begin{array}{c}\text { Need for hospitalization }(\mathrm{n}=69) \\
\text { Yes } \\
\text { No }\end{array}$ & $\begin{array}{l}02 \\
67\end{array}$ & $\begin{array}{c}2,89 \\
97,10\end{array}$ \\
\hline
\end{tabular}

Table.4 Acidity (pH and titratable acidity) and density of milk and nonnonkoumou samples.

\begin{tabular}{|c|c|c|c|}
\hline & \multicolumn{3}{|c|}{ Parameters } \\
\hline Samples & $\mathrm{pH}$ & Titratable acidity $(\%)$ & Density \\
\hline PM1 & $6,1 \pm 0,007^{\mathrm{e}}$ & $0,23 \pm 0,007^{\mathrm{d}}$ & $1,060 \pm 0,02^{\mathrm{ab}}$ \\
\hline PM2 & $6,2 \pm 0,02^{\mathrm{d}}$ & $0,22 \pm 0,01^{\mathrm{d}}$ & $1,071 \pm 0,02^{\mathrm{ab}}$ \\
\hline PM3 & $5,9 \pm 0,02^{\mathrm{f}}$ & $0,36 \pm 0,01^{\mathrm{c}}$ & $1,040 \pm 0,01^{\mathrm{a}}$ \\
\hline PM4 & $6,5 \pm 0,01^{\mathrm{c}}$ & $0,17 \pm 0,007^{\mathrm{e}}$ & $1,029 \pm 0,01^{\mathrm{b}}$ \\
\hline RM1 & $6,5 \pm 0,007^{\mathrm{b}}$ & $0,06 \pm 0,02^{\mathrm{g}}$ & $1,053 \pm 0,02^{\mathrm{ab}}$ \\
\hline RM2 & $6,4 \pm 0,01^{\mathrm{c}}$ & $0,08 \pm 0,02^{\mathrm{fg}}$ & $1,072 \pm 0,02^{\mathrm{ab}}$ \\
\hline RM3 & $6,7 \pm 0,007^{\mathrm{a}}$ & $0,1 \pm 0,01^{\mathrm{f}}$ & $1,045 \pm 0,01^{\mathrm{b}}$ \\
\hline RM4 & $6,7 \pm 0,007^{\mathrm{a}}$ & $0,08 \pm 0,007^{\mathrm{fg}}$ & $1,029 \pm 0,01^{\mathrm{b}}$ \\
\hline Nnk1 & $3,9 \pm 0,02^{\mathrm{g}}$ & $1,34 \pm 0,007^{\mathrm{b}}$ & $0,832 \pm 0,02^{\mathrm{c}}$ \\
\hline Nnk2 & $3,7 \pm 0,001^{\mathrm{h}}$ & $1,39 \pm 0,02^{\mathrm{a}}$ & $0,860 \pm 0,01^{\mathrm{c}}$ \\
\hline Nnk3 & $3,7 \pm 0,007^{\mathrm{i}}$ & $1,4 \pm 0,007^{\mathrm{a}}$ & $0,841 \pm 0,007^{\mathrm{c}}$ \\
\hline
\end{tabular}

PM1, PM2, PM3, PM4: Pasture milk 1, 2, 3 and 4; RM1, RM2, RM3, RM4: reseller milk 1, 2, 3 and 4; Nnk1, Nnk2, Nnk3: Nonnonkoumou (artisanal milk curd) 1,2 and 3. The same letter in the same column indicated no statistical difference $(\mathrm{P}>0.05)$. 
Table.5 Identification of Salmonella in milk and nonnonkoumou samples

\begin{tabular}{|l|c|}
\hline & Germe \\
\hline Samples & Salmonella \\
\hline PM1 & + \\
\hline PM2 & - \\
\hline PM3 & + \\
\hline PM4 & - \\
\hline RM1 & + \\
\hline RM2 & - \\
\hline RM3 & - \\
\hline RM4 & - \\
\hline Nnk1 & - \\
\hline Nnk2 & - \\
\hline Nnk3 & - \\
\hline
\end{tabular}

PM1, PM2, PM3, PM4: Pasture milk 1, 2, 3 and 4; RM1, RM2, RM3, RM4: reseller milk 1, 2, 3 and 4; Nnk1, Nnk2, Nnk3: Nonnonkoumou (artisanal milk curd) 1, 2 and 3.

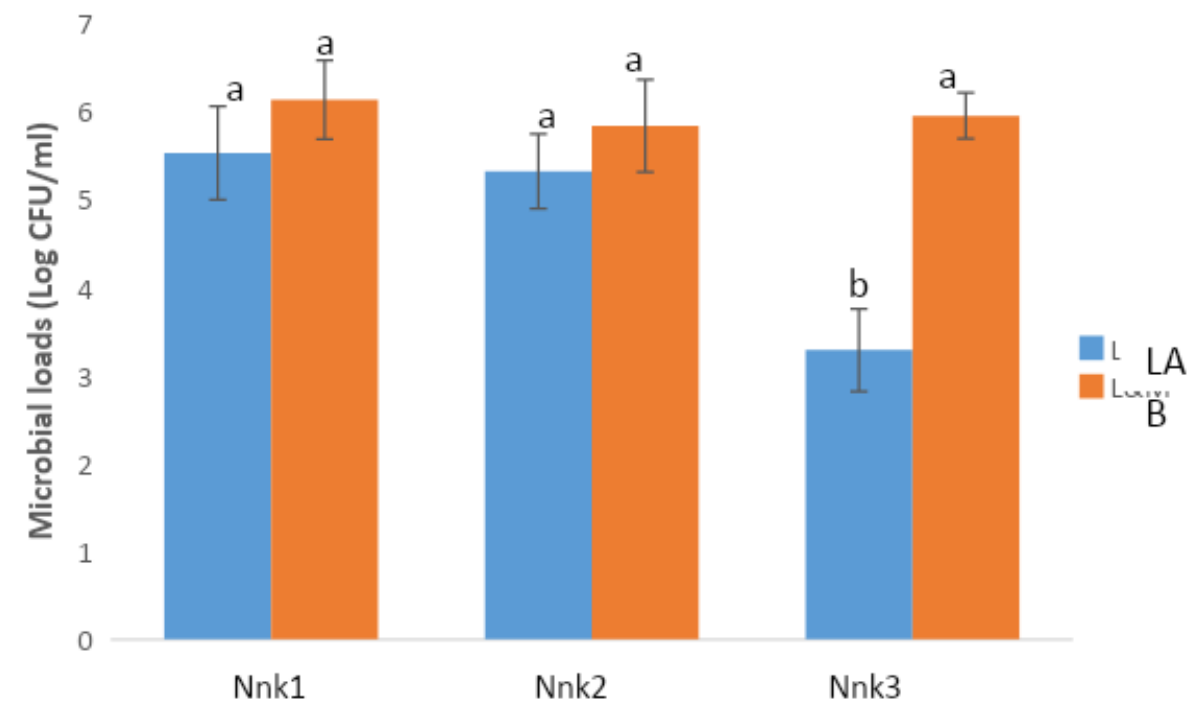

Fig.3 Lactic acid bacteria and yeasts and molds (fermenting microorganisms) populations in nonnonkoumou samples taken from sellers. Values at each time point are the means of our replicates \pm SD (error bars). LAB: Lactic acid bacteria, Y\&M: Yeast and molds. Nnk1, Nnk2, Nnk3: Nonnonkoumou (artisanal milk curd) 1,2 and 3 . For the same type of germ, histograms bearing the same alphabetical letter are not statistically different $(\mathrm{P}>0.05)$ (Tukey, HSD). 


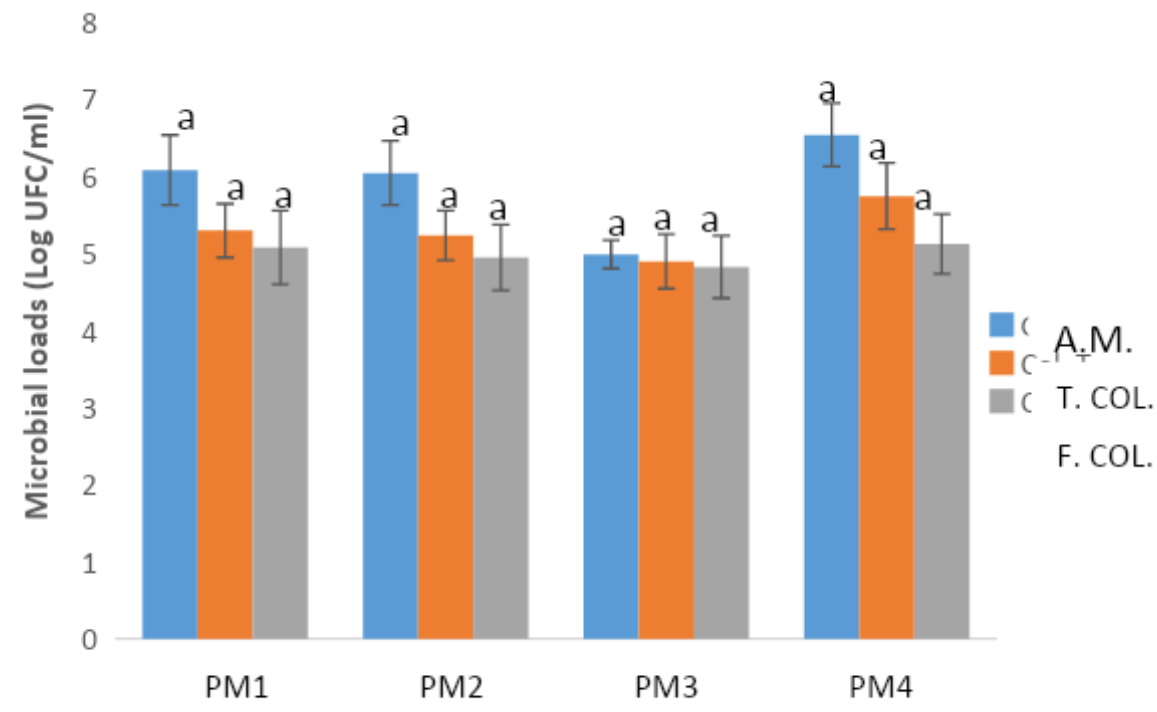

Fig.4 Aerobic mesophiles, total and fecal coliforms populations (non fermenting microorganisms) in milk samples taken from pastures. Values at each time point are the means of our replicates \pm SD (error bars). A.M.: Aerobic mesophiles, T. COL. Total coliforms, F. COL.: Fecal coliforms. PM1, PM2, PM3, PM4: Pasture milk 1, 2, 3 and 4. For the same type of germ, histograms bearing the same alphabetical letter are not statistically different $(\mathrm{P}>0.05)$ (Tukey, HSD).

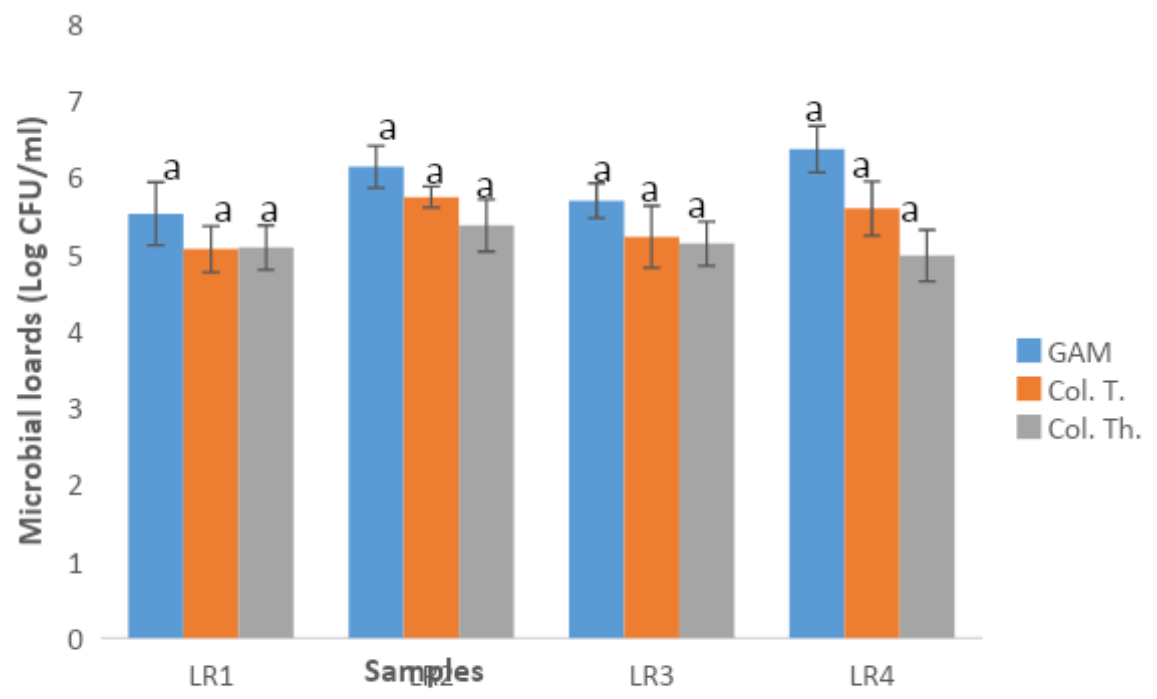

Fig. 5. Aerobic mesophiles, total and thermotolerant coliforms populations (non fermenting microorganisms) in milk samples taken from resellers. Values at each time point are the means of our replicates \pm SD (error bars). A.M.: Aerobic mesophiles, T. COL. Total coliforms, F. COL.: Fecal coliforms. RM1, RM2, RM3, RM4: reseller milk 1, 2, 3 and 4. For the same type of germ, histograms bearing the same alphabetical letter are not statistically different $(\mathrm{P}>0.05)$ (Tukey, HSD). 


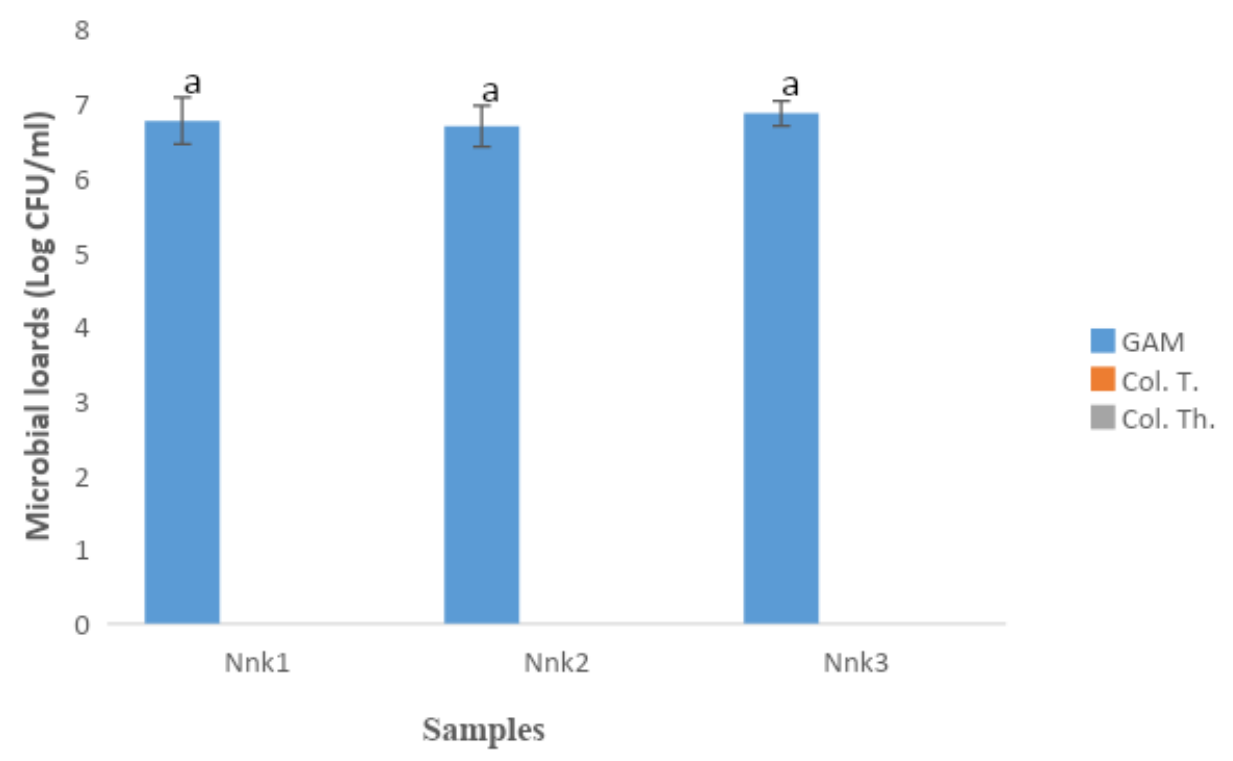

Fig.6 Aerobic mesophiles, total and fecal coliforms populations (non fermenting microorganisms) in nonnonkoumou samples taken from sellers. Values at each time point are the means of our replicates \pm SD (error bars). A.M.: Aerobic mesophiles, T. COL. Total coliforms, F. COL.: Fecal coliforms. Nnk1, Nnk2, Nnk3: Nonnonkoumou (artisanal milk curd) 1, 2 and 3. For the same type of germ, histograms bearing the same alphabetical letter are not statistically different $(\mathrm{P}>0.05)$ (Tukey, HSD).

Raw cow's milk is a staple food that is increasingly consumed by Côte d'Ivoire populations, particularly in Daloa town. The proof is that, during the survey on milk consumption, $100 \%$ of the people questioned (150) stated that they know raw cow's milk and consume it regularly (100\%). They consume it at least once a day, preferably at breakfast (45.33\%) and pay between 100 and 200 FCFA. These populations opted preferentially for boiled milk (40.67\%), followed by fermented milk or nonnonkoumou (32\%). In addition, some people surveyed $(46 \%)$ reported having had ailments following the consumption of milk.

These ailments, most commonly characterized by diarrhea (89.85\%) and gastroenteritis $(10.15 \%)$, are usually attributed to the ingestion of a bad cooking food and / or having been subject to defective manipulations (Olshansky et al., 1997, Farthing, 2000). These conditions, marked by a high rate of diarrhea and gastroenteritis, are characteristic of the infections especially caused by sulphito-reducers Clostridium (Cassin et al., 1998). Cow's milk is consumed raw, boiled or fermented (nonnonkoumou). Indeed, the raw milk taken from the pastures and from the sellers has a $\mathrm{pH}$ varied from 5.9 \pm 0.02 to $6.7 \pm 0.007$ relatively in conformity with the standards (IDF, 1995) which fixes the milk pH between 6.4 and 6.7.

On the other hand, the $\mathrm{pH}$ of nonnonkoumou samples is low $(3.7 \pm 0.001$ to $3.9 \pm 0.02)$ associated with titratable acidity levels ranging from $1.4 \pm 0.007$ to $1.34 \pm 0.007$. This considerable drop in $\mathrm{pH}$ in nonnonkoumou compared to milk is related to the fermentation that takes place during the manufacture of this food. Indeed, the decrease in $\mathrm{pH}$ suggests the presence and activity of $\mathrm{LAB}$ during the spontaneous fermentation of milk. LAB produce organic acids, mainly lactic and acetic acids, which induce a 
lowering of pH (Coulin et al., 2006; Panda et al., 2007).

The rise in titratable acidity with the corresponding decline in $\mathrm{pH}$ during fermentation has been reported by several authors in studies on various African traditional foods such as mawe, sorghum beer and ogi (Hounhouigan et al., 1999; Sawadogo-Lingani et al., 2008; Oyarekua et al., 2008). Moreover, the density of the milk taken from the pasture 4 and from the reseller 4 is equal to $1.029 \pm 0.01$ and that of the milk taken from the other 3 pastures and the other 3 resellers varied from $1.045 \pm 0.01$ to 1.071 \pm 0.01 .

The nonnonkoumou samples density varied from $0.832 \pm 0.02$ to $0.860 \pm 0.01$. Thus, a density of less than 1.028 indicates the addition of water in the milk (wet milk) while a density greater than 1.032 indicates that the milk has been heated or skimmed. We can therefore deduce that the milk taken from the pasture 4 and that taken from the reseller 4 are normal milks.

These milks were not heated or added water. On the other hand, the milk of the 3 other pastures and the milk of the 3 other resellers having a density higher than 1.032 would have been heated before the commercialization. In addition, the density of nonnonkoumou below 1.028 could be explained by the addition of water to milk before or after the production of this curd.

The density of the milk also varies according to the dry matter content and the fat content. Thus it decreases with the increase of fat (Mahamedi, 2015). The microbiological parameters of milk and nonnonkoumou were also analyzed in this study. Indeed, the results obtained have shown the presence of LAB and yeasts and molds, in raw milk and in artisanal curd milk (nonnonkoumou). These microorganisms have had been previously isolated in some food and fermented food. These fermentative germs are abundant in the milk samples but especially in the nonnonkoumou samples and present a similar evolution.

The abundance of these microorganisms during fermentation is due to their tolerance to acidic conditions. They commonly play very important roles in the production of a range of traditional maize and cerealbased fermented foods and beverages, including koko (Lei \& Jakobsen, 2004) and gowé (Vieira-Dalode et al., 2007) and have also previously been reported to be present in high numbers in fermented dough for doklu production (Assohoun et al., 2012). It has also been reported that LAB that survive the fermentation processes usually do this in association with yeasts (Sanni, 1993).Indeed, these microorganisms (yeasts and LAB) are common in traditional fermented foods (Nyanga et al., 2007).

A co-metabolism between these microorganisms has been suggested by Gobbetti et al., (1994). During this cometabolism, LAB provide an acidic environment, which encourages the growth of yeasts, and yeasts provide vitamins and other growth factors for LAB. Yeasts would also make a useful contribution to the flavor and acceptability of fermented products according to Banigo et al., (1974). The variation in the concentration of lactic acid bacteria from one sample of nonnonkoumou to another may be explained by the fact that the technological processes used to manufacture this product differ from one producer to another. This variation may also depend on the initial milk composition of lactic acid bacteria and especially the storage conditions of this food (Ndiaye, 2002). These lactic acid bacteria produce several aromatic compounds, enzymes and other compounds that have a profound effect on the texture and taste of 
dairy products (Ngassam 2007). On the other hand, the milk collected from the resellers was free of yeasts and molds.

This absence of yeast and mold in our milk samples is probably due to the pasteurization of the milk before marketing. In fact, the milk taken from the sellers had a high temperature (around $70^{\circ} \mathrm{C}$ ). Yeasts and molds are said to be heat-sensitive, that is, they do not tolerate high temperatures at all, hence the extermination of their population in these milk samples. Other microorganisms (total coliforms, fecal coliforms and aerobic mesophiles) were also present in samples analyzed in this study. Indeed, large GAM and coliform loads were detected in the different samples of milk and nonnonkoumou, and these charges varied from one pasture to another and from one reseller to another.

These contaminating germs certainly had to contaminate the milk during milking on pasture under generally unsanitary environmental conditions. Indeed, the surrounding air, the utensils used to extract milk and water could be the main sources of milk contamination. Guiraud (1998) has indeed indicated that such elements (water, utensils, etc.) are major sources of contamination of food products.

Also, the non-compliance with the rules of hygiene by the sellers, the transport conditions of milk of the pastures to the sale places, the dust as well as the flies which arise on the ladle serving as a measure during the sale, could also be contamination sources. Millogo et al., (2018) have demonstrated that containers used during milking and in the manufacture of fermented milk can cause contamination of the milk as well as the final product. In addition, Ndiaye in 2002 stated that the milk $\mathrm{pH}$ is favorable for microorganisms development, but their number decreased as the fermented milk aged. In addition, total and thermotolerant coliforms were detected in large number in all milk samples collected from pastures and resellers.

The incidence of coliforms in raw milk has received considerable attention, partly due to their association with contamination of fecal origin and the consequent risk of more pathogenic fecal organisms being present, partly because of the spoilage their growth in milk at ambient temperatures can produce. The presence of coliforms in dairy products is not acceptable by safe food consumption standards. These organisms are highly pathogenic and may cause serious diseases for human.

Coliform counts regularly in excess of $2 \log$ are considered as evidence of unsatisfactory production hygiene (Directive 92/46/EEC, 1992). Sporadic high coliform counts may also be a consequence of unrecognized coliform mastitis, mostly caused by E. coli (Torkar et al., 2008). On the other hand, the nonnonkoumou samples analyzed were free of coliforms. This phenomenon is certainly due to the acidity of this food that has a low $\mathrm{pH}$ (below 4). This low $\mathrm{pH}$ prevents the growth of most spoilage and pathogenic organisms (Varga, 2007).

Such results have already been reported by some authors (Nout et al., 1989, Marsha et al., 1998, Karamoko et al., 2012) in their work on fermented foods. Also Steinkraus (1996) specified that coliforms do not tolerate low $\mathrm{pH}$. This disappearing of coliforms was certainly due to the sensitivity of these bacteria to the substances produced by LAB. It was proved that LAB exert antimicrobial action through the production of lactic and acetic acids, bacteriocins, diacetyl and hydrogen peroxide (Daeschel, 1989). In addition, the salmonella presence was observed in the milk samples from pasture 1 and 3 and also from the reseller 3 . The presence of salmonella in the milk of pasture 1 (PM1) and 3 (PM3) could be related to 
contamination of the cows by this germ that has surely contaminated the milk. This presence may also be due to non-compliance with the rules of hygiene by the shepherds of pastures 1 and 3 during milking.

The presence of pathogenic bacterial species such as $S$. aureus, E. coli and Salmonella sp is a real danger for consumers of this food (Kouassi et al., 2018). The presence of Salmonella in the milk collected from seller 3 may be associated with poor pasteurization of contaminated milk on pasture or during transport. It may also be due to recontamination of the milk after pasteurization due to poor hygienic practices.

On the other hand, Salmonella were not detected in nonnonkoumou samples, other pastures and milk other vendors. Their absence in the nonnonkoumou would be related to the acidity of the product which could inhibit the salmonella growth. These results are in agreement with those of Elham et al., (2011) who found that all their samples of fermented dairy products were found free of Salmonella in Liban. These samples also comply with the standard provided by AFNOR in 1999 (fermented milks are free of Salmonella).

The main objective of this study was to study the physicochemical and microbiological parameters of milk collected from pastures, from women sellers and also from producers of nonnonkoumou in the Daloa city. A survey conducted to determine the knowledge, mode and frequency of milk consumption has showed that the milk is known and consumed by many Ivorians and some nationals of neighboring countries of all age and any social level. Milk consumption was associated with pathologies and the symptoms of food poisoning observed required very little medical intervention. The results of the physicochemical analyzes showed that the $\mathrm{pH}$ of the milk taken from the pastures and from the resellers was relatively high compared to the $\mathrm{pH}$ of the nonnonkoumou. '

These results have also shown that some milk samples are normal while some have been pasteurized before marketing or have been water added. Moreover, the results of the microbiological analyzes showed the total disappearance of the yeasts and molds in the milk taken from the sellers and also an absence of total and thermotolerant coliforms in the nononkoumou samples analyzed.

These results also showed the absence of Salmonella in the majority of samples analyzed. On the other hand, the milk of pastures 1 and 3, as well as that of seller 1 , contained this germ. The presence of Salmonella which is a pathogenic flora in these samples demonstrates that this milk is a poor microbiological quality. Its consumption can automatically lead to food poisoning.

\section{References}

Assohoun N.M.C., Djéni N.T., N'Guessan K.F. \& Koussemon M. (2012). Preliminary study on antimicrobial properties of lactic acid bacteria involved in the fermentation of corn dough during Doklu processing in Côte d'Ivoire. Food (Global Science Books), 6, 65-70.

AFNOR (Association Française de Normalisation). (1999). Microbiologie Alimentaire:Méthodes horizontales tome 1 (7e édn), Sciences et techniques agroalimentaires. AFNOR : Paris ; $663 p$.

Banigo E.O.I., De Man J.M. \& Duitschaever C.L. (1974). Utilization of high-lysine corn for the manufacture of $o g i$ using a new improved processing system. Cereal Chemistry, 51, 559-572.

Cassin M.H., Lammerding A.M., Todd E.C., Ross W. \& McColl R.S. (1998). Quantitative risk assessment for 
Escherichia coli O157:H7 in ground beef hamburgers. International Journal Food Microbiology, 41, 21-44.

Coulin P., Farah Z, Assanvo J, Spillman H \& Puhan Z. (2006) Characterization of the microflora of attiéké, a fermented cassava product during traditional small-scale production. International journal of food Microbiology. 106, 131136.

Daeschel, M. A. (1989). Antimicrobial substances from lactic acid bacteria for use as food preservatives. Food Technology, 43, 164-167.

Das, S., Hasan, A. and Parveen, S. 2015. Evaluation of microbial load and quality of milk and milk based dairy products. Octa Journal of Biosciences 3:1-4.

Directive 92/46/EEC (1992). Council Directive 92/46/EEC of 16 June 1992 laying down the health rules for the production and placing on the market of raw milk, heat-treated milk and milkbased products. Official J.L 268 (1409).1-31. Available at: http://ec.europa.eu/food/fs/sfp/mr/mr03 _en.pdf.

Elham H.S, Hussein D, Roula A.R \& Mabelle C. (2011). Caractérisation chimique et qualité bactériologique de produits laitiers caprins traditionnels libanais. Lebanese Science Journal, 12 (1), 2129.

FAO. 2013. Milk and Dairy Products in Human Nutrition. Food and Agricultural Organization of the United Nations, Rome, Italy.

Farthing M.J.G. (2000). Diarrhoea: a significant worldwide problem, International Journal of antimicrobial agent, 14: 65-69.

Gobbetti M., Corsetti A. \& Rossi J. (1994). The sourdough microflora. Interactions between lactic acid bacteria and yeasts: metabolism of carbohydrates. Applied Microbiology and Biotechnology, 41,
456- 460.

Guiraud J.P. (1998). Microbiologie alimentaire. Edition DUNOD, Paris, $615 \mathrm{p}$.

Hounhouigan D.J., Nout M.J.R., Nago C.M., Houben J.H. \& Rombouts F.M. (1999). Use of starter cultures of lactobacilli and yeast in the fermentation of mawe, an African maize product. Tropical Science, 39, 220-226.

IDF / FIL. Fédération Internationale de Laiterie (1995), Bruxelles, Belgique, $\mathrm{P}$ $34-36$.

Jespersen L., Halm M. Kpodo K. \& Jacobson M. (1994). Significance of yeasts and moulds occurring in maise dough fermentation for kenkey production. International Journal of Food Microbiology, 24, 239-248.

Jespersen, L., Halm, M., Kpodo, K., \& Jakobsen, M. (1994). Significance of yeasts and moulds occurring in maize dough fermentation for Kenkey production. International Journal of Food Microbiology, 24, 239-248.

Karamoko D., Djeni N.T., N'guessan K.F., Bouatenin K.M.J-P. \& Dje K.M. (2012). The biochemical and microbiological quality of palm wine samples produced at different periods during tapping and changes which occured during their storage. Food Control, 26, 504-511.

Kèkè $M$, Yèhouénou $B$, de Souza C, Sohounhloué DCK. 2009. Evaluation of hygienic and nutritional quality of peulh cheese treated by Sorghum vulgaris (L) and Pimenta racemosa (Miller) extracts. Scientific Study \& Research, 10(1): 2946.

Kimaryo V.M., Massawe G.A., Olusapo N.A. \& Holzapfel W.M. (2000). The use of starter culture in the fermentation of cassava for the production of "Kivunde" a traditional Tanzanian food product. International Journal of Food 
Microbiology, 56, 179-190.

Kouassi K.C., Voko D-R.R.B., Koffi A.C., Kouame K.B.E. \& koffi-Nevry R. (2018). Microbial contamination of the non-alcoholic beverage Gnamakoudji made from Zingiber officinale in Daloa, Côte d'Ivoire. African Journal of Microbiology Research, 12(35), 857865.

Lei V. \& Jakobsen M. (2004). Microbiological characterization and probiotic potential of koko and koko sour water, African spontaneously fermented millet porridge and drink. Journal Applied of Microbiology, 96, 384-397.

Mahamedi, A. (2015). Etude des qualités hygiéniques, physico-chimiques et microbiologiques des ferments et des beurres traditionnelles destinés à la communication dans déférents régions d'Algérie. Thèse de Doctorat, Université Oran. Algérie.P 16.

Marsha G.G.K., Ipsen M.A., Petersen M.A. \& Jakobsen M. (1998). Microbiological, rheological and aromatic characteristics of fermented uji (an East African sour porridge). World Journal of Microbiology and Biotechnology, 14, 451-456.

Millogo V, Sissao M. \& Ouédraogo GA. (2018). Qualité nutritionnelle et bactériologique des échantillons de quelques produits laitiers locaux de la chaîne de production au Burkina Faso. Int. J. Biol. Chem. Sci., 12(1): 244-252, DOI https://dx.doi.org/10.4314/ijbcs.v12i1.1 9.

Mirah-dpp (2012). Annuaire des statistiques des ressources animales et halieutiques. Direction de la Planification et des programmations, Ministère de Ressources Animales et Halieutiques, Abidjan, Côte d'Ivoire, 26 p.

Muehlhoff, E., Bennett A. \& McMahon D.
(2013). Milk and dairy products in human nutrition.

Ndiaye M. (2002). Contribution à l'étude de conformité de l'étiquetage de la qualité microbiologique des yaourts commercialisés à Dakar. Thèse de Doctorat, Université Cheikh AntaDiop de Dakar, Dakar P. 11.

Ngassam TC. (2007). Caractérisation de la flore lactique des laits fermentés artisanaux au Sénégal : cas de la zone de Niaye. Thèse de Doctorat, Université Cheikh Anta Diop de Dakar, Dakar, 109p.

Nout M.J.R., Rombouts F.M. \& Havelaar A. (1989). Effect of natural lactic fermentation of infant food ingredients on some pathogenic microorganisms. International Journal of Food Microbiology, 8, 351-361.

Nyanga L. K., Nout M. J. R., Gadaga T. H., Theelen B., Boekhout T. \& Zwietering M. H. (2007). Yeasts and lactic acid bacteria microbiota from masau (Ziziphus mauritiana) fruits and their fermented fruit pulp in Zimbabwe. International Journal of Food Microbiology, 120, 159-166.

OCDE/FAO (2016), « Lait et produits laitiers », dans Perspectives agricoles de l'OCDE et de la FAO 2016-2025, Éditions OCDE, Paris. DOI: http://dx.doi.org/10.1787/agr_outlook20 16-11-fr.

Olshansky S., Carnes B., Rogers R. \& Smith. L. (1997). Infectious diseases - New and ancient threats to world health. Population Bulletin, 52, 2-43.

Oyarekua M.A. Akinyele I.O., Treche S. \& Eleyinmi A.F. (2008) Amylolytic lactic acid bacteria fermentation of maizecowpea "ogi". Journal of Food Processing and Preservation. 31, 286305.

Pal M. (2007). Zoonoses. 2nd Ed. Satyam Publishers, Jaipur, India. 
Panda S.H., Parmanick M \& Ray R.C. (2007). Lactic acid fermentation of sweet potato (Ipomoea batatas L.) into pickles. Journal of food processing and Preservation.31, 83-101.

Pointurier H. (2003). La gestion matières dans l'industrie laitière. Tec et Doc, Lavoisier, France, 388 p.

Sanni, A. I. (1993). The need for process optimization of African fermented foods and beverages. International Journal of Food Microbiology, 18, 85-95.Banigo et al., (1974).

Sawadogo-Lingani H., Diawara1 B., Traoré A.S. \& Jakobsen M. (2008). Technological properties of lactobacillus fermentum involved in the processing of dolo and pito, West African sorghum beers, for the selection of starter cultures. Journal of Applied Microbiology 104, 873-882.

Steinkraus K.H. (1996). Handbook of Indigenous Fermented Foods. 2nd edn. Marcel Dekker, New York 1996, ISBN $0824793528,792 \mathrm{p}$.

Torkar KG, Teger SG (2008). The microbiological quality of raw milk after introducing the two day's milk collecting system. Acta Agric. Slovenica. 92(1).61-74.

Varga L (2007). Microbiological quality of commercial dairy products. Communicating Current Research and Educational Topics and Trends in Applied Microbiology, A. MéndezVilas (Ed.). pp. 487-494.

Vieira-Dalode G., Jespersen, L., Hounhouligan J., Moller P.L., Nago, C.M. \& Jakobsen M. (2007). Lactic acid bacteria and yeasts associated with gowe production from sorghum in Benin. Journal of Applied Microbiology, 103, 342-349.

Youan-Bi A. (2008) Efficacité managériale des éleveurs de bovins en Côte d'Ivoire: cas des départements de Toumodi et de Korhogo, Thèse Unique de doctorat de l'Université de Cocody, UFR Sciences Economiques et de Gestion, $170 \mathrm{pp}$, Soutenue le 28 juin 2008, Abidjan. [Managerial efficiency of cattle in Côte d'Ivoire: case of departments of Toumodi and Korhogo].

\section{How to cite this article:}

Assohoun-Djeni Nanouman Marina Christelle, Kouassi Kouassi Clément, Kouassi Kra Athanase, Yao Kouassi Cédric, Djeni N'dédé Théodore, Konate Ibrahim. 2020. Physicochemical Characteristics and Microbial Contamination of Raw Milk and Artisanal Milk Curd (Nonnon koumou) in Daloa, Côte D'ivoire. Int.J.Curr.Microbiol.App.Sci. 9(03): 26672683. doi: https://doi.org/10.20546/ijcmas.2020.903.305 